\title{
Characterization of allele-specific expression of the X-linked gene MAO-A in trophectoderm cells of bovine embryos produced by somatic cell nuclear transfer
}

\author{
A.R. Ferreira' ${ }^{1,4}$, L.F.C. Aguiar Filho ${ }^{1}$, R.V. Sousa ${ }^{1}$, R. Sartori ${ }^{4,5}$ and M.M. Franco ${ }^{1,2,3}$ \\ 'Laboratório de Reprodução Animal, Embrapa Recursos Genéticos e Biotecnologia, \\ Brasília, DF, Brasil \\ ${ }^{2}$ Faculdade de Medicina Veterinária, Universidade Federal de Uberlândia, \\ Uberlândia, MG, Brasil \\ ${ }^{3}$ Instituto de Genética e Bioquímica, Universidade Federal de Uberlândia, \\ Uberlândia, MG, Brasil \\ ${ }^{4}$ Departmento de Reprodução Animal e Radiologia Veterinária, \\ Escola de Medicina Veterinária e Zootecnia, \\ Universidade Estadual de São Paulo "Júlio de Mesquita Filho", \\ Botucatu, SP, Brasil \\ ${ }^{5}$ Departamento de Zootecnia, Escola Superior de Agricultura Luiz de Queiroz, \\ Universidade de São Paulo, Piracicaba, SP, Brasil \\ Corresponding author: M.M. Franco \\ E-mail: mauricio.franco@embrapa.br
}

Genet. Mol. Res. 14 (4): 12128-12136 (2015)

Received May 7, 2015

Accepted July 23, 2015

Published October 5, 2015

DOI http://dx.doi.org/10.4238/2015.October.5.26

ABSTRACT. Somatic cell nuclear transfer (SCNT) may affect epigenetic mechanisms and alter the expression of genes related to embryo development and $\mathrm{X}$ chromosome inactivation $(\mathrm{XCl})$. We characterized allele-specific expression of the $\mathrm{X}$-linked gene monoamine oxidase type $\mathrm{A}$ (MAO-A) in the trophectoderm (TF) of embryos produced by SCNT. Total RNA was isolated from individual biopsies $(\mathrm{N}=25)$, and the allele-specific 
expression assessed by reverse transcription-polymerase chain reactionrestriction fragment length polymorphism. Both paternal and maternal alleles were expressed in the trophectoderm. However, a higher frequency of the mono-allelic expression of a specific allele was observed $(\mathrm{N}=17 ; 68 \%)$, with the remaining samples showing the presence of mRNA from both alleles ( $\mathrm{N}$ $=8 ; 32 \%)$. Considering that MAO-A is subject to $\mathrm{XCl}$ in bovine, our results suggest that SCNT may influence $\mathrm{XCl}$ because neither an imprinted (monoallelic expression in all samples) nor a random (presence of mRNA from both alleles in all samples) pattern of $\mathrm{XCl}$ was observed in TF. Due to the importance of $\mathrm{XCl}$ in mammalian embryo development and its sensitivity to in vitro conditions, $\mathrm{X}$-linked genes subject to $\mathrm{XCl}$ are candidates for use in the development of embryo quality molecular markers for assisted reproduction.

Key words: Cloning; Trophectoderm; MAO-A; X chromosome inactivation

\section{INTRODUCTION}

Somatic cell nuclear transfer (SCNT) is a powerful reproductive technique for animal cloning and transgenic animal production, and has great potential for regenerative medicine and stem cell applications. Despite its widespread use in domestic animals, the efficiency of SCNT remains low. Most cloned embryos are eliminated in utero, and the few that develop to term show a high incidence of abnormalities, for example, changes in the $\mathrm{X}$ chromosome inactivation $(\mathrm{XCl})$ process (Xue et al., 2002; Nolen et al., 2005; Oikawa et al., 2014), and placentation abnormalities (Young et al., 1998; Xue et al., 2002; Chavatte-Palmer et al., 2012). XCl equalizes the expression of X-linked genes between the sexes (Lyon, 1961; Heard and Disteche, 2006) through a mechanism known as dosage compensation; an aberrant establishment of this process may prevent embryo development. As $\mathrm{XCl}$ is one of the most important events of early mammalian embryonic development, controlled by epigenetic mechanisms, it may serve as an important molecular indicator of embryo quality.

In marsupials, $\mathrm{XCl}$ proceeds by imprinting, through which the paternal $X(X p)$ is selected for inactivation (Cooper et al., 1971). In humans, $\mathrm{XCl}$ occurs randomly in embryonic and extraembryonic tissues (Moreira de Mello et al., 2010). In mice, however, XCl occurs initially through imprinting (Takagi and Sazaki, 1975), silencing Xp from the 4- to 8-cell stage, followed by random $\mathrm{XCl}$ in the inner cell mass (ICM) (Okamoto et al., 2004; Navarro et al., 2008, 2010). This second process is accompanied by several molecular events, including expression of the X-inactive specific transcript (Xist) and regulation by its antisense transcript, Tsix (Escamilla-Del-Arenal et al., 2011). X chromosome inactivation occurs earlier in mice than in rabbits and humans (Okamoto et al., 2011), which may be explained by an identified need for rapid pre-implantation development in this species (Okamoto et al., 2005).

Although $\mathrm{XCl}$ affects the majority of the $\mathrm{X}$ chromosome, several $\mathrm{X}$-linked genes are known to escape the inactivation process (Berletch et al., 2015). These genes are actively expressed in the context of silenced chromatin (Boggs et al., 2002) and have an important role in determining sex differences (Heard and Disteche, 2006; Berletch et al., 2015). The gene monoamine oxidase type $\mathrm{A}(\mathrm{MAO}-\mathrm{A})$ is located on the $\mathrm{X}$ chromosome, and is subject to $\mathrm{XCl}$ (Benjamin et al., 2000; Xue et al., 2002; Stabellini et al., 2009). Xue et al. (2002) demonstrated random mono-allelic expression of $M A O-A$, confirming that this gene is subject to $\mathrm{XCl}$ in cattle. After $\mathrm{XCl}$ establishment, therefore, each embryonic cell has only one active allele in cattle. 
De La Fuente et al. (1999) and Bermejo-Alvarez et al. (2011) suggested that XCl begins around the blastocyst stage in bovine embryos. In a previous experiment conducted in our laboratory (Ferreira et al., 2010), we characterized allele-specific expression of MAO-A in bovine embryos produced in vitro. In that study, we detected the presence of MAO-A mRNA of maternal origin only at the morula stage, and both maternal and paternal MAO-A mRNA at the blastocyst stage, thus reinforcing that the blastocyst stage is an important developmental period of $\mathrm{XCl}$ in cattle.

Considering that $\mathrm{XCl}$ is an essential event ensuring normal embryo development, and that placentation abnormalities are important causes of low efficiency of SCNT (Chavatte-Palmer et al., 2012), the characterization of X-linked gene expression in the trophoblastic lineage is an important strategy for improving our understanding of SCNT procedures. Accordingly, the aim of this study was to characterize allele-specific expression of MAO-A in the trophectoderm of bovine embryos produced by SCNT.

\section{MATERIAL AND METHODS}

Experiments were approved by the Ethics Committee on Animal Use (ECAU-protocol No. 98/2010) at the School of Veterinary Medicine and Animal Science of Universidade Estadual Paulista "Júlio de Mesquita Filho".

\section{Ovary collection, in vitro maturation (IVM), and oocyte selection}

We used ovaries from crossbred cows (Bos taurus taurus x Bos taurus indicus) obtained from a local slaughter house and transported in saline $(0.9 \% \mathrm{NaCl})$ supplemented with penicillin $\mathrm{G}(100 \mathrm{IU} / \mathrm{mL})$ and streptomycin sulfate $(100 \mathrm{ng} / \mathrm{mL})$ at $35^{\circ} \mathrm{C}$. Cumulus oocyte complexes (COCs) were aspirated from follicles $3-8 \mathrm{~mm}$ in diameter. Only COCs with a homogeneous granulated cytoplasm and at least three layers of compact of cumulus cells were used in the study. Selected COCs were graded I and II and transferred in groups of 20-25 to $200 \mu \mathrm{L}$ maturation medium, covered with silicone oil, and incubated for $22 \mathrm{~h}$ at $39^{\circ} \mathrm{C}$ and $5 \% \mathrm{CO}_{2}$ in air. Maturation medium consisted of TCM - 199 Earle's salts supplemented with 10\% fetal bovine serum (FBS) (both Invitrogen, Carlsbad, CA, USA); $0.01 \mathrm{IU} / \mathrm{mL}$ follicle-stimulating hormone (Sigma, Carlsbad, CA, USA); $0.1 \mathrm{mg} / \mathrm{mL}$ glutamine, and antibiotic (amikacin; $0.075 \mathrm{mg} / \mathrm{mL}$ ). After IVM for $20 \mathrm{~h}$, oocytes were denuded using hyaluronidase (Sigma). Oocytes were then evaluated for the presence of the first polar body (PB) under a stereomicroscope SMZ645 (Nikon Corporation, Konan, Minato-ku, Tokyo, Japan); those with a PB were selected for nuclear transfer (NT).

\section{Somatic cell culture}

Skin fibroblasts from a female Nellore cow were maintained in vitro as nuclei donors for the NT procedure. The cow was approximately 30 months old and had been previously genotyped by polymerase chain reaction-restriction fragment length polymorphism (PCR-RFLP) as heterozygous (AG) for MAO-A. Cells were grown in $25-\mathrm{cm}^{2}$ bottles at $39^{\circ} \mathrm{C}$ and $5 \% \mathrm{CO}_{2}$ in air, in Dulbecco's Minimum Eagle Medium (GIBCO, Life Technologies, Carlsbad, CA, USA) supplemented with $3.7 \mathrm{~g} / \mathrm{L}$ sodium bicarbonate, $110 \mathrm{mg} / \mathrm{L}$ pyruvate, $10 \% \mathrm{FBS}$, and antibiotics. Frozen straws of $0.25 \mu \mathrm{L}$ containing skin fibroblasts were removed from liquid nitrogen $\left(-196^{\circ} \mathrm{C}\right)$ and thawed in a $37^{\circ}-38^{\circ} \mathrm{C}$ water bath, then maintained in vitro as donor nuclei for up to seven passages. 
NT

After incubation for $30 \mathrm{~min}$ in synthetic oviduct fluid with amino acids, citrate and myoinositol (SOFaaci) solution containing $0.33 \mathrm{mg} / \mathrm{mL}$ cytochalas in D and $7.5 \mathrm{~mL}$ Hoechst 3342 (Sigma), oocytes were separated into groups of 16 to 20 . Oocytes were individually fixed on a holding pipette and positioned such that the PB would remain in the four o'clock position. The PB and a portion of adjacent cytoplasm were removed by aspiration without breaking the cytoplasmic membrane. Subsequently, through the same hole opened in the zona pellucida, a somatic cell was placed in the perivitelline space. Next, both structures were subjected to the process of electrofusion in a fountain ECM200 BTX (Genetronics Inc., San Diego, CA, USA) by generating electrical pulses with two loads of $2.1 \mathrm{kVA} / \mathrm{cm}$ for $30 \mu \mathrm{s}$, in a $0.28 \mathrm{MD}$-mannitol solution containing $0.1 \mathrm{mM} \mathrm{\textrm {MSO } _ { 4 }}$ (both Sigma) in a melting chamber for $30 \mathrm{~min}$. Next, the activation process was performed, in which the fused structure underwent incubation for $5 \mathrm{~min}$ in SOFaaci with $5 \mu \mathrm{M}$ ionomycin (Sigma), followed by 4-h incubation in SOFaaci with 2 mM 6DMAP (Sigma).

\section{In vitro embryo culture}

Following NT, structures were co-cultured for 8 days in SOFaaci under a cumulus cell monolayer at $39^{\circ} \mathrm{C}$ and $5 \% \mathrm{CO}_{2}$ in air. Embryos were evaluated at 48, 168, and $192 \mathrm{~h}$ [days (D) 2 , 7 and 8 , respectively] for cleavage rate evaluation and blastocyst formation.

\section{Micromanipulation for trophectoderm isolation}

At D8, embryos were evaluated and expanded blastocysts $(N=25)$ biopsied to separate the trophectoderm from the ICM. Expanded blastocysts were chosen for biopsy to ensure the effective separation of trophoblast cells from the ICM, because at that developmental stage, it can be quite simple to distinguish the two tissues. Biopsies were performed manually using a micromanipulator M\&M (M\&M - The Micromanipulator Microscope Company, Escondido, CA, USA) and stainless steel blades at angles of 15 degrees (Bio-Cut ${ }^{\circledR}$-Blades Feather, Feather Safety Razor Co, Chome Kita-Ku, Osaka, Japan). Embryos were micro-manipulated on a $100 \times 20 \mathrm{~mm}$ Petri dish containing $200 \mu \mathrm{L}$ maintenance medium consisted of TCM - 199 Hank'ssalts supplemented with $10 \%$ FBS (both Invitrogen) and antibiotic (amikacin; $0.075 \mathrm{mg} / \mathrm{mL}$ ).

\section{RNA extraction and reverse transcription}

Total RNA was isolated from individual trophectoderm biopsies using the Arcturus ${ }^{\circledR}$ PicoPure RNA Isolation Kit (Life Technologies), according to the manufacturer instructions. Following RNA isolation, samples were incubated with 1 U DNAse I (Invitrogen), and reverse transcribed using 200 $\mathrm{U}$ of SuperScript III (200 U/mL; Invitrogen) and $0.5 \mu \mathrm{g}$ of oligo-dT ${ }_{12-18}$ primer $(0.5 \mu \mathrm{g} / \mu \mathrm{L}$; Invitrogen). The reverse transcription protocol reaction was carried out for $5 \mathrm{~min}$ at $65^{\circ} \mathrm{C}, 42^{\circ} \mathrm{C}$ for $52 \mathrm{~min}$, then enzyme inactivation at $70^{\circ} \mathrm{C}$ for $15 \mathrm{~min}$.

\section{RT-PCR-RFLP for MAO-A}

To detect and characterize allele-specific expression of MAO- $A$, cDNA from individual trophectoderm biopsies $(\mathrm{N}=25$ ) was used as a template for nested PCR. RT-PCR-RFLP was 
performed according to Ferreira et al. (2010), with minor modifications. Briefly, $4 \mu \mathrm{L}$ cDNA was used in the first round of amplification, then $1 \mu \mathrm{L}$ amplicon from the first round was used as a template for the second round. Amplification reactions contained $2 \mu \mathrm{L} \mathrm{PCR}$ buffer; $1 \mathrm{mM} \mathrm{MgCl}$; $200 \mathrm{nM}$ of each dNTP; $5 \mu \mathrm{M}$ of each inner/outer primer; and $1 \mathrm{U}$ Platinum Taq DNA polymerase (Life Technologies), in a final volume of $20 \mu \mathrm{L}$. Amplification was performed using the following conditions: initial denaturing at $94^{\circ} \mathrm{C}$ for $3 \mathrm{~min} ; 40$ cycles of $94^{\circ} \mathrm{C}$ for $30 \mathrm{~s}$, annealing at either $52^{\circ} \mathrm{C}$ (outer) or $56^{\circ} \mathrm{C}$ (inner) for $30 \mathrm{~s}$ and extension at $72^{\circ} \mathrm{C}$ for $40 \mathrm{~s}$; then final extension at $72^{\circ} \mathrm{C}$ for 10 min. After both rounds of PCR, amplicon $(13 \mu \mathrm{L})$ was incubated overnight at $37^{\circ} \mathrm{C}$ with $13 \mathrm{U} R$ sal restriction enzyme (New England Biolabs, Ipswich, MA, EUA). Alleles were detected using a $3 \%$ agarose $(\mathrm{w} / \mathrm{v})$ gel stained with ethidium bromide $(10 \mathrm{mg} / \mathrm{mL})$ and photographed under UV light. The "A" allele produces a 106-bp fragment whereas the "G" allele produces two fragments of 84 and 22 bp, as described by Xue et al. (2002) and Ferreira et al. (2010). As negative controls, PCRs were performed in the absence of a cDNA template.

\section{Data analysis}

Both "A" and "G" MAO-A alleles were identified by analyzing amplicon sizes on an agarose gel, and descriptive analysis was performed by calculating the allele frequencies.

\section{RESULTS}

Twenty-five cloned embryos were biopsied, and MAO- $A$ allele-specific expression analysis performed in all trophectoderm biopsies (Figure 1). Representative RT-PCR-RFLP patterns of trophectoderm biopsies are shown in Figure 2. The allele-specific expression frequency for MAO-A is shown in Table 1. The "A" allele was expressed in all biopsies, whereas the " $G$ " allele was only expressed in eight trophectoderm biopsies (Table 1). A higher frequency of mono-allelic expression of the "A" allele was observed ( $N=17 ; 68 \%$ of total biopsies), with a lower frequency of the biopsies showing the presence of mRNA from both the "A" and the " $G$ " alleles ( $N=8 ; 32 \%$; Table 1).

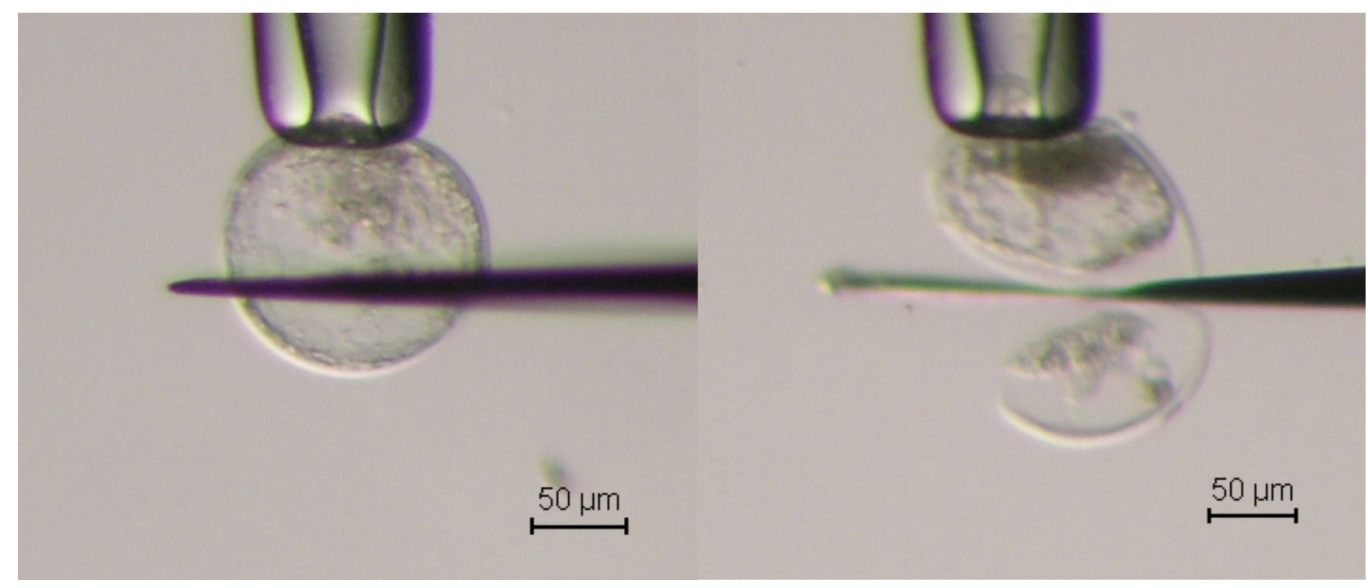

Figure 1. Biopsy procedure. An expanded blastocyst positioned to be biopsied. The trophectoderm is positioned below and the inner cell mass (darker cells) above the blade. 


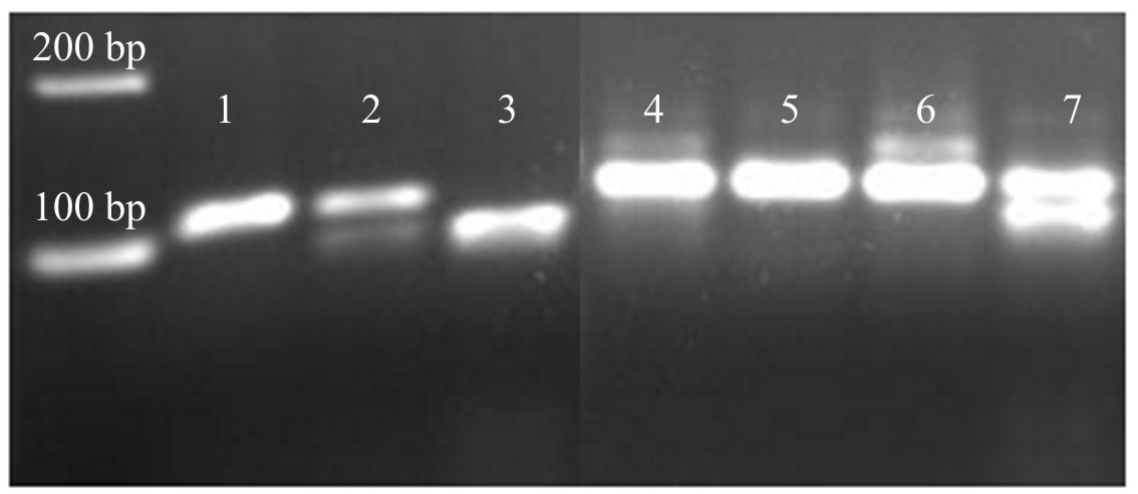

Figure 2. RT-PCR-RFLP results for MAO-A from individual trophectoderm samples, on $2.5 \%$ agarose $(\mathrm{w} / \mathrm{v}) \mathrm{gel}$. Controls are genomic DNA: lane 1 = AA; lane 2 = AG and lane $3=\mathrm{GG}$. Lanes 4, 5, and 6 show only the "A" allele; lane 7 shows both "A" and "G" alleles.

Table 1. Frequency of allelic-specific expression of MAO-A in trophectoderm biopsies of cloned bovine embryos.

\begin{tabular}{lccc}
\hline Tissue & mRNA & Embryos $(\mathrm{N})$ & Frequency $(\%)$ \\
\hline Trophectoderm $(\mathrm{N}=25)$ & $\mathrm{A}$ & 17 & 68 \\
& $\mathrm{G}$ & Not detected & Not detected \\
& $\mathrm{AG}$ & 8 & 32 \\
\hline
\end{tabular}

\section{DISCUSSION}

We have previously described the allele-specific expression pattern in bovine embryos produced in vitro from the 4-cell stage to the expanded blastocyst stage (Ferreira et al., 2010) for MAO-A, which is subject to XCl (Benjamin et al., 2000, Xue et al., 2002; Stabellini et al., 2009). In that study, we detected only the maternal allele at the morula stage, and both alleles were detected at the expanded blastocyst stage. A similar pattern was found in mice (Okamoto and Heard, 2009).

In the present study, we characterized MAO-A allele-specific expression in single trophectoderm biopsies from bovine cloned embryos. The "A" allele was expressed in all biopsies, with the " $G$ " allele expressed in only eight biopsies. A higher frequency of mono-allelic expression of the "A" allele was observed with a lower frequency of the biopsies showing the presence of mRNA from both "A" and "G" alleles.

Although cloning by SCNT is widely used, the efficiency of this technique is low (Cibelli et al., 2002). There is a consensus in the literature that aberrant epigenetic reprogramming of the somatic cell genome is the initial cause of this low efficiency (Reik et al., 2001; Blelloch et al., 2006; Eilertsen et al., 2007) and induces later placentation abnormalities, which are frequently observed in cloned animal pregnancies (Young et al., 1998; Chavatte-Palmer et al., 2012). Morgan et al. (2005) suggested that incomplete epigenetic reprogramming occurs in the majority of cloned embryos, resulting in an aberrant gene expression pattern and abnormal embryonic development.

The process of $\mathrm{XCI}$, first described by Lyon (1961), is established during early mammalian embryonic development by epigenetic mechanisms such as DNA methylation and histone modification (Plath et al., 2002). Although $\mathrm{XCl}$ affects the majority of the $\mathrm{X}$ chromosome, several 
genes located on this chromosome are known to escape the inactivation process (Berletch et al., 2015), unlike MAO-A, which is subject to XCl (Benjamin et al., 2000; Xue et al., 2002; Stabellini et al., 2009). Yang et al. (2007) commented that $\mathrm{XCl}$ can be aberrantly established in cloned embryos due to imprinting pattern alterations in the placenta. Therefore, characterization of the allele-specific expression patterns of genes located on the $\mathrm{X}$ chromosome in cloned embryos can contribute to understanding the effects of SCNT procedures on epigenetic reprogramming in embryos.

Five decades have passed since $\mathrm{XCl}$ was first described. Nevertheless, the role of genomic imprinting (Xue et al., 2002; Zeng and Yankowitz, 2003; Senda et al., 2004, Nolen et al., 2005; Smith et al., 2005; Ferreira et al., 2010; Bermejo-Alvarez et al., 2011) remains to be determined for different species with the exception of mice, in which the process is relatively well established (Eggan and Jaenish, 2003). Yang et al. (2007) reported that cloned embryos have a tendency for preferential $\mathrm{X}$ inactivation in trophectoderm cells, based on an imprinting pattern that follows the pattern of $\mathrm{X}$ inactivation from the donor cell genome.

We used 25 MAO-A heterozygous donor cells (AG genotype) to produce the embryos evaluated in this study. The adult skin fibroblasts originally came from the ICM of an embryo. XCI occurs randomly in ICMs, and once established, chromosome silencing is stable and heritable through subsequent cell divisions due to preferential inactivation (Brockdorff, 2011). Therefore, considering a preferential inactivation that follows the pattern of $X$ inactivation from the donor cell (Yang et al., 2007), it would be expected that approximately $50 \%$ of biopsies would show "A" mono-allelic expression, and $50 \%$ would show " $G$ " mono-allelic expression. On the other hand, if we consider that a correct event of $X$ reactivation occurs in the earliest divisions of embryonic cells and considering a random process of $X$ silencing, we would predict all trophectoderm samples show the presence of both alleles as we analyzed a pool of cells in each biopsy. The same pattern of MAO-A expression would be expected, if we consider that $\mathrm{XCI}$ has not yet been established at this stage of development. This would be in agreement with Bermejo-Alvarez et al. (2011), who suggested that $\mathrm{XCl}$ commences around the blastocyst stage in cattle. However, our results are not in agreement with either pattern. Neither an imprinted/preferential nor a random pattern of expression was found. Instead, we have detected a prevalence of mono-allelic expression favoring the "A" allele in the majority of samples. Some studies have shown aberrant expression of X-linked genes in placenta (Senda et al., 2004; Nolen et al., 2005, Yang et al., 2007), although Smith et al. (2005) found no evidence of abnormal X-linked gene expression in blastocyst-stage embryos. Bourc'his et al. (2001) commented that aberrant DNA methylation reprogramming occurs in SCNT bovine embryos. Importantly, Liu et al. (2008) showed aberrant DNA methylation patterns in four imprinted genes including MAO-A, in spontaneously-aborted SCNT-cloned fetuses. Dean et al. (2001) reported that epigenetic reprogramming occurs incompletely and is aberrant in most cloned embryos. Morgan et al. (2005) also reported aberrant gene expression and abnormal embryonic development in cloned embryos. Experiments conducted at later stages of development found biallelic expression of genes linked to the $X$ chromosome in placenta from deceased clones. However, only one active $X$ chromosome was found in the placenta from animals that survived to term (Xue at al., 2002). Although our results do not allow us to affirm that both $X$ chromosomes are expressed in the same cell, we detected both MAO-A alleles in $32 \%$ of trophectoderm samples, supporting the possibility of an aberrant bi-allelic expression of MAO-A in some cells. This possibility could be confirmed by genome-wide transcriptional analysis of cloned embryos, which has revealed alterations in X-linked gene expression and in genes involved in XCl (Inoue et al., 2010), and by an aberrant DNA methylation pattern found in the MAO-A differentially methylated region of aborted 
SCNT-cloned fetuses (Liu et al., 2008). Furthermore, Nolen et al. (2005) showed that SCNT mouse embryos could reactivate the silent $X$ chromosome, although reactivation may be incomplete; this possibility could support our results. Based on these data, we suggest that the SCNT procedure altered the allele-specific expression pattern of MAO- $A$ in trophectoderm cells. Considering this gene is subject to $\mathrm{XCl}$, and based on our results and from those reported in the literature (Dean et al., 2001; Bourc'his et al., 2001; Senda et al., 2004; Nolen et al. 2005, Morgan et al., 2005, Inoue et al., 2010; Matoba et al., 2011), we speculate that the SCNT procedure may influence XCI establishment in cloned embryos.

The results presented here may contribute to a better understanding of XCl during SCNT, and of the effects of in vitro manipulations on gene expression and embryo quality. Due to the relevance of the $\mathrm{XCl}$ process in general and for correct placentation for carrying pregnancies to term, $\mathrm{X}$-linked genes subject to $\mathrm{X}$ inactivation are important candidate genes in the development of molecular markers for embryo quality in assisted reproduction.

\section{Conflicts of interest}

The authors declare no conflict of interest.

\section{ACKNOWLEDGMENTS}

Research supported by Empresa Brasileira de Pesquisa Agropecuária (EMBRAPA) and Conselho Nacional de Desenvolvimento Científico e Tecnológico (CNPq), Brazil. We thank FAPESP (process \#2010/07971-3) for the scholarship granted to the first author.

\section{REFERENCES}

Benjamin D, van Bakel I and Craig IW (2000). A novel expression based approach for assessing the inactivation status of human X-linked genes. Eur. J. Hum. Genet. 8: 103-108.

Berletch JB, Ma W, Yang F, Shendure J, et al. (2015). Escape from X inactivation varies in mouse tissues. PLoS Genet. 11: e1005079.

Bermejo-Alvarez P, Rizos D, Lonergan P and Gutierrez-Adan A (2011). Transcriptional sexual dimorphism in elongating bovine embryos: implications for $\mathrm{XCl}$ and sex determination genes. Reproduction 141: 801-808.

Blelloch R, Wang Z, Meissner A, Pollard S, et al. (2006). Reprogramming efficiency following somatic cell nuclear transfer is influenced by the differentiation and methylation state of the donor nucleus. Stem Cells 24: 2007-2013.

Boggs BA, Cheung P, Heard E, Spector DL, et al. (2002). Differentially methylated forms of histone H3 show unique association patterns with inactive human X chromosomes. Nat. Genet. 30: 73-76.

Bourc'his D, Le Bourhis D, Patin D, Niveleau A, et al. (2001). Delayed and incomplete reprogramming of chromosome methylation patterns in bovine cloned embryos. Curr. Biol. 11: 1542-1546.

Brockdorff N (2011). Chromosome silencing mechanisms in X-chromosome inactivation: unknown unknowns. Development 138: 5057-5065.

Chavatte-Palmer P, Camousa S, Jammes H, Le Cleac'h N, et al. (2012). Review: Placental perturbations induce the developmental abnormalities often observed in bovine somatic cell nuclear transfer. Placenta 33 (Suppl): S99-S104.

Cibelli JB, Lanza RP, Campbell KH and West MD (2002). Principles of Cloning. 1st edn. Academic Press, San Diego.

Cooper DW, Vandeberg JL, Sharman GB and Poole WE (1971). Phophoglyterate kinase polymorphism in kangaroos provides further evidence for paternal X inactivation. Nat. New Biol. 230: 155-157.

De La Fuente R, Hahnel A, Basrur PK and King WA (1999). X inactive-specific transcript (Xist) expression and X chromosome inactivation in the preattachment bovine embryo. Biol. Reprod. 60: 769-775.

Dean W, Santos F, Stojkovic M, Zakhartchenko V, et al. (2001). Conservation of methylation reprogramming in mammalian development: aberrant reprogramming in cloned embryos. Proc. Natl. Acad. Sci. U. S. A. 98: 13734-13738. 
Eggan K and Jaenisch R (2003). Micromanipulating dosage compensation: understanding X-chromosome inactivation through nuclear transplantation. Semin. Cell Dev. Biol. 14: 349-358.

Eilertsen KJ, Power RA, Harkins LL and Misica P (2007). Targeting cellular memory to reprogram the epigenome, restore potential, and improve somatic cell nuclear transfer. Anim. Reprod. Sci. 98: 129-146.

Escamilla-Del-Arenal M, da Rocha ST and Heard E (2011). Evolutionary diversity and developmental regulation of X-chromosome inactivation. Hum. Genet. 130: 307-327.

Ferreira AR, Machado GM, Diesel TO, Carvalho JO, et al. (2010). Allele-specific expression of the MAOA gene and $X$ chromosome inactivation in in vitro produced bovine embryos. Mol. Reprod. Dev. 77: 615-621.

Heard E and Disteche CM (2006). Dosage compensation in mammals: fine tuning the expression of the X chromosome. Genes Dev. 20: 1848-1867.

Inoue K, Kohda T, Sugimoto M, Sado T, et al. (2010). Impeding Xist expression from the active X chromosome improves mouse somatic cell nuclear transfer. Science 330: 496-499.

Liu J, Yin S, Xiong B, Hou Y, et al. (2008). Aberrant DNA methylation imprints in aborted bovine clones. Mol. Reprod. Dev. 75: 598-607.

Lyon MF (1961). Gene action in the X-chromosome of the mouse (Mus musculus L.). Nature 190: 372-373.

Matoba S, Inoue K, Kohda T, Sugimoto M, et al. (2011). RNAi-mediated knockdown of Xist can rescue the impaired postimplantation development of cloned mouse embryos. Proc. Natl. Acad. Sci. U. S. A. 108: 20621-20626.

Moreira de Mello JC, de Araújo ES, Stabellini R, Fraga AM, et al. (2010). Random X inactivation and extensive mosaicism in human placenta revealed by analysis of allele-specific gene expression along the X chromosome. PLoS One 5: e10947.

Morgan HD, Santos F, Green K, Dean W, et al. (2005). Epigenetic reprogramming in mammals. Hum. Mol. Genet. 14 Spec No. 1: R47-R58.

Navarro P, Chambers I, Karwacki-neisius V, Chureau C, et al. (2008). Molecular coupling of Xist regulation and pluripotency. Science 321: 1693-1695.

Navarro P, Oldfield A, Legoupi J, Festuccia N, et al. (2010). Molecular coupling of Tsix regulation and pluripotency. Nature 468: 457-460.

Nolen LD, Gao S, Han Z, Mann MR, et al. (2005). X chromosome reactivation and regulation in cloned embryos. Dev. Biol. 279: 525-540.

Oikawa M, Inoue K, Shiura H, Matoba S, et al. (2014). Understanding the $\mathrm{X}$ chromosome inactivation cycle in mice: a comprehensive view provided by nuclear transfer. Epigenetics 9: 204-211.

Okamoto I and Heard E (2009). Lessons from comparative analysis of X-chromosome inactivation in mammals. Chromosome Res. 17: 659-669.

Okamoto I, Otte AP, Allis CD, Reinberg D, et al. (2004). Epigenetic dynamics of imprinted X inactivation during early mouse development. Science 303: 644-649.

Okamoto I, Arnaud D, Le Baccon P, Otte AP, et al. (2005). Evidence for de novo imprinted X-chromosome inactivation independent of meiotic inactivation in mice. Nature 438: 369-373.

Okamoto I, Patrat C, Thépot D, Peynot N, et al. (2011). Eutherian mammals use different strategies to initiate X-chromosome inactivation during development. Nature 472: 370-374.

Plath K, Mlynarczyk-Evans S, Nusinow DA and Panning B (2002). Xist RNA and the mechanism of X chromosome inactivation. Annu. Rev. Genet. 36: 233-278.

Reik W, Dean W and Walter J (2001). Epigenetic reprogramming in mammalian development. Science 293: 1089-1093.

Senda S, Wakayama T, Yamazaki Y, Ohgane J, et al. (2004). Skewed X-inactivation in cloned mice. Biochem. Biophys. Res. Commun. 321: 38-44.

Smith SL, Everts RE, Tian XC, Du F, et al. (2005). Global gene expression profiles reveal significant nuclear reprogramming by the blastocyst stage after cloning. Proc. Natl. Acad. Sci. U. S. A. 102: 17582-17587.

Stabellini R, Vasques LR, de Mello JC, Hernandes LM, et al. (2009). MAOA and GYG2 are submitted to X chromosome inactivation in human fibroblasts. Epigenetics 4: 388-393.

Takagi $\mathbf{N}$ and Sasaki M (1975). Preferential inactivation of the paternally derived $X$ chromosome in the extraembryonic membranes of the mouse. Nature 256: 640-642.

Xue F, Tian XC, Du F, Kubota C, et al. (2002). Aberrant patterns of X chromosome inactivation in bovine clones. Nat. Genet. 31: 216-220.

Yang X, Smith SL, Tian XC, Lewin HA, et al. (2007). Nuclear reprogramming of cloned embryos and its implications for therapeutic cloning. Nat. Genet. 39: 295-302.

Young LE, Sinclair KD and Wilmut I (1998). Large offspring syndrome in cattle and sheep. Rev. Reprod. 3: 155-163.

Zeng SM and Yankowitz J (2003). X-inactivation patterns in human embryonic and extra-embryonic tissues. Placenta 24: 270-275. 